\title{
Environment shapes invertebrate assemblage structure differences between volcanic spring- fed and runoff rivers in northern California
}

\author{
Robert A. Lusardi ${ }^{1,4}$, Michael T. Bogan ${ }^{2,5}$, Peter B. Moyle ${ }^{1,6}$, and Randy A. Dahlgren ${ }^{1,7}$ \\ ${ }^{1}$ Center for Watershed Sciences, University of California, Davis, California 95616 USA \\ ${ }^{2}$ School of Natural Resources and the Environment, University of Arizona, Tucson, Arizona 85719 USA
}

\begin{abstract}
Flow variability plays an important role in structuring lotic communities, yet comparatively little is known about processes governing assemblage dynamics in stream ecosystems with stable environmental conditions, such as spring-fed rivers. Volcanic spring-fed rivers (hereafter spring-fed rivers) occur in geologically active landscapes of the western USA and around the globe. We sampled invertebrate assemblages and quantified primary productivity and habitat characteristics of spring-fed and runoff rivers in northern California over 4 seasons. We predicted that abiotic factors would be more stable and nutrient availability greater and that invertebrate density would be greater and diversity lower in spring-fed than in runoff rivers. Runoff rivers exhibited high variability in discharge and temperature, whereas spring-fed rivers were relatively stable with high naturally occurring nutrient levels. On average, $\mathrm{NO}_{3}{ }^{-}$and $\mathrm{PO}_{4}{ }^{3-}$ concentrations were $40 \times$ greater in spring-fed than in runoff rivers. Spring-fed rivers supported nearly 7 to $16 \times$ greater densities of invertebrates than runoff systems, depending on season. However, invertebrate species richness was greater in runoff rivers in all seasons. Spring-fed river invertebrate assemblages were strongly correlated with elevated nutrient concentrations and basal C sources, whereas runoff assemblages were associated with discharge variability and median substrate size. We suggest that strong differences in abiotic variability between spring-fed and runoff rivers play an important role in determining invertebrate assemblage structure. Because spring-fed rivers exhibit more stable temperatures throughout the year and lower temperatures during the summer than runoff rivers, they may provide essential refugia for coldwater taxa in a warming climate.
\end{abstract}

Key words: volcanic spring-fed rivers, community structure, abiotic stability, disturbance, nutrients, flow regime

Flow regimes are widely regarded as having high explanatory power regarding biological trends and patterns in lotic ecosystems. As a result, many investigators have focused on the magnitude and frequency of peak events and their direct effects on biotic communities (Townsend et al. 1997, Death and Zimmermann 2005, Greenwood and Booker 2014). Fluctuations in discharge can cause mortality directly through high- and low-flow events, but they also influence temperature, nutrient availability, food resources, habitat structure, and species interactions (Peckarsky et al. 1990, Stanley et al. 1994, Freeman et al. 2001, Allan and Castillo 2007). All of these factors can affect aquatic community composition. For example, invertebrate diversity was positively correlated with increasing stream temperature in a study by Jacobsen et al. (1997), and Barquín and Death (2011) suggested that temperature variability can facilitate increased invertebrate diversity in streams. Less understood, however, is the response of stream invertebrate communities to relatively stable environmental conditions.

Flow regimes of most rivers are dominated by runoff events, but spring-fed systems are primarily regulated by groundwater discharge and may show little to no response to local precipitation events. Volcanic spring-fed rivers (henceforth, spring-fed rivers) are underlain by young volcanic terrains that promote deep regional groundwater flow and stable discharge at springhead locations (Tague and Grant 2009). Consequently, abiotic drivers most responsible for structuring aquatic invertebrate communities in runoff-dominated rivers (henceforth, runoff rivers), such as discharge and temperature, show comparatively minimal seasonal variation in spring-fed rivers (Tague and Grant 2004, Tague et al. 2007, Lusardi 2014). Stable environmental conditions coupled with naturally occurring nutrient inputs also may enhance invertebrate density in spring-

E-mail addresses: ${ }^{4}$ ralusardi@ucdavis.edu; ${ }^{5}$ michaelthomasbogan@gmail.com; ${ }^{6}$ pbmoyle@ucdavis.edu; ${ }^{7}$ radahlgren@ucdavis.edu

DOI: 10.1086/687114. Received 5 August 2015; Accepted 11 February 2016; Published online 4 May 2016.

Freshwater Science. 2016. 35(3):1010-1022. ๑ 2016 by The Society for Freshwater Science. 
fed systems when compared with runoff rivers (Barquín and Death 2004). While the hydrologic and geomorphic nature of spring-fed rivers has been documented (Whiting and Stamm 1995, Whiting and Moog 2001), we know comparatively little about how these systems function ecologically (Cantonati et al. 2012).

The mechanisms influencing species abundance and diversity are complex, but the need to understand them is urgent because stream ecosystems are changing rapidly as a result of land use, water withdrawals, and climate change (NRC 2004, Stewart et al. 2005). Coldwater habitat in the western USA and elsewhere is projected to decline significantly with decreasing summer base flows and increasing stream temperatures (Stewart et al. 2005, Bryant 2009, Wenger et al. 2011). These 2 climate-induced effects may have a negative synergistic effect on coldwater biota as the time between elevated summer water temperature and autumn base flow declines (Arismendi et al. 2013). Springfed rivers may exhibit more stable temperatures throughout the year and lower temperatures during critical summer periods and, therefore, potentially provide important refuge habitat for stream invertebrates and other native coldwater biota.

We compared invertebrate communities and environmental variables across multiple seasons in spring-fed and runoff rivers in northern California, USA. Our objectives were to understand how spring-fed rivers function ecologically through time, explore the mechanisms influencing invertebrate community structure within these ecosystems, and consider the potential role of spring-fed rivers as coldwater refuges in a rapidly changing climate. We predicted that abiotic factors would be more stable and nutrient availability higher in spring-fed than in runoff rivers and that invertebrate density would be greater and diversity lower.

\section{METHODS}

\section{Study sites}

We conducted our study in the upper Sacramento River basin of northern California, a large watershed $\left(10,129 \mathrm{~km}^{2}\right)$ encompassing 3 primary subbasins including the upper Sacramento, McCloud, and lower Pit Rivers. Significant portions of the watershed are managed by the US Forest Service for recreation, grazing, agriculture, and timber harvest, whereas other portions are privately owned. The basin includes parts of both the Cascade Range and Klamath Mountains geomorphic provinces and has variable geology, including young volcanic rock and older metamorphic and sedimentary rock (Rose et al. 1996). Most precipitation in the region falls as snow during winter, but hydrologic pathways to rivers vary greatly depending on geology. In volcanic portions of the drainage, snowmelt is routed through deep subsurface flow paths that recharge aquifers and support large spring-fed rivers. In metamorphic and sedimentary portions of the basin, snowmelt travels as overland or shallow subsurface flow to runoff rivers. We examined invertebrate assemblage structure and environmental variables in 3 spring-fed (Hat Creek, Fall River, and Rising River) and 3 runoff rivers (South Fork Sacramento River, Castle Creek, McCloud River) in the upper Sacramento River basin (Fig. 1). Study streams ranged between 12 and $29 \mathrm{~m}$ wide with discharge between $\sim 1.1$ and $99.1 \mathrm{~m}^{3} / \mathrm{s}$ depending on season and sampling period.

\section{Data collection}

At each river, we delineated a 50-m sampling reach based on geomorphic similarity between stream types (spring-fed vs runoff). We collected stream temperature and stage data at 30-min intervals for the entire 12-mo period (October 2012-October 2013) with HOBO Pro v2 (Onset Computer Corporation, Bourne, Massachusetts) water temperature data loggers and Global Water WL-16 (Global Water Instrumentation, College Station, Texas) submersible pressure transducers. We collected water samples monthly at each site to quantify suspended chlorophyll and water chemistry $\left(\mathrm{pH}, \mathrm{NO}_{2}{ }^{-}+\mathrm{NO}_{3}{ }^{-}\left[\mathrm{NO}_{3}-\mathrm{N}\right]\right.$, and soluble reactive $\left.\mathrm{PO}_{4}{ }^{3-}\left[\mathrm{SR}-\mathrm{PO}_{4}{ }^{3-}\right]\right)$. We used the ammonium molybdate spectrophotometric method (limit of detection $[\mathrm{LOD}] \approx 0.005 \mathrm{mg} / \mathrm{L}$ ) to measure SR-PO ${ }_{4}{ }^{3-}$ (APHA 1998) and the vanadium chloride spectrophotometric method to measure $\mathrm{NO}_{3}-\mathrm{N}(\mathrm{LOD}=0.01 \mathrm{mg} / \mathrm{L}$ ) (Doane and Horwáth 2003). We sampled suspended chlorophyll by filtering $1000 \mathrm{~mL}$ of water through a precombusted glass-fiber filter $(\mathrm{GF} / \mathrm{F})$ in the field. We freeze-dried filters and extracted chlorophyll with $90 \%$ ethanol prior to quantification by fluorometry and converted to pigment concentration (chlorophyll $a[\mathrm{chl} a]$ and pheophytins) (APHA 1998). We characterized bed particle size following Wolman (1954) and calculated median particle size $\left(D_{50}\right)$ for each river.

We collected stream invertebrates and particulate organic matter seasonally (October 2012, January, May, and July 2013) at each site. We randomly selected 3 transect lines at each 50-m reach and sampled each transect at 3 locations (left, center, right) across the wetted width of the reach. We collected invertebrates by disturbing $0.09 \mathrm{~m}^{2}$ of substratum to a depth of $\sim 6 \mathrm{~cm}$ while capturing entrained invertebrates immediately downstream in a D-net (500- $\mu \mathrm{m}$ mesh). We composited invertebrate samples for each transect to yield 3 composite samples (each with sampled area $=0.27 \mathrm{~m}^{2}$ ) for each river reach. In the laboratory, we used a Folsom plankton splitter to subsample each sample to reach a minimum count of 500 organisms if the sample contained $>500$ individuals [ind]. Otherwise, we identified all invertebrates in the sample. Stream insects and most noninsect taxa were identified to lowest practical level (usually genus or species) with the aid of keys published by Merritt et al. (2008), Wiggins (1996), Smith (2001), and Thorp and Covich (2001), as well as various taxon-specific references. We identified oli- 


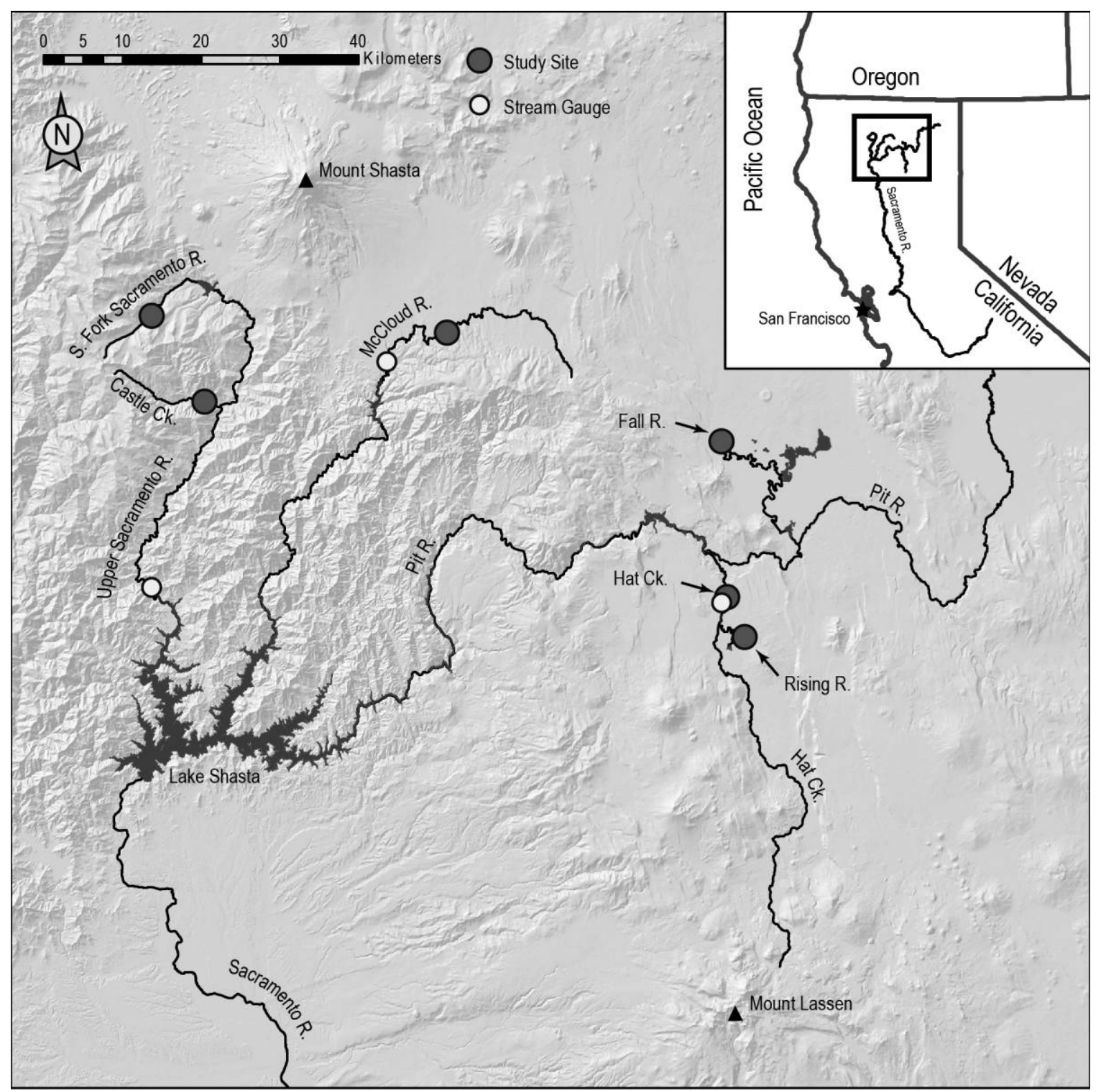

Figure 1. Site locations in the upper Sacramento River drainage.

gochaetes to class and freshwater leeches (Glossiphoniidae) and fingernail clams (Sphaeriidae) to family. We also classified taxa into functional trait groups based on information published by Merritt et al. (2008).

We collected particulate organic matter (POM) samples with the same procedures as for invertebrates $(n=3$ sites/season), but we offset the transect lines by $1 \mathrm{~m}$ to ensure that we were not resampling a previously disturbed area. We stored POM samples frozen until we processed them in the laboratory. We thawed the samples and separated particles into 2 size classes, fine particulate organic matter (FPOM $<1 \mathrm{~mm}$ ) and coarse particulate organic matter $(\mathrm{CPOM}>1 \mathrm{~mm})$ with the aid of a $1-\mathrm{mm}$-mesh sieve. We dried each FPOM and CPOM sample individu- ally at $60^{\circ} \mathrm{C}$ for $\geq 48 \mathrm{~h}$ and weighed it on an analytical balance $( \pm 0.01 \mathrm{~g})$. We combusted dried samples in a muffle furnace at $475^{\circ} \mathrm{C}$ for $90 \mathrm{~min}$ or until the entire sample consisted of ash. We cooled the samples and reweighed them before calculating ash-free dry mass (AFDM g) of POM by subtracting the mass of inorganic residue from the precombustion dry mass.

We collected 3 epilithic algae samples from each stream during each seasonal sampling period. Each sample consisted of 3 cobbles selected from previously delineated transects at locations not previously disturbed by invertebrate or POM sampling. We used a small brush to remove biofilm from a $6.45-\mathrm{cm}^{2}$ area from each cobble, rinsed the biofilm into a tray, and transferred the composite sample 
into a sterile sample bag. We immediately enclosed the samples in a dark bag and placed them on dry ice where they remained frozen until processing. In the laboratory, we thawed and filtered samples through a precombusted GF/F. We recorded the volume of sample water for each sample to account for dilution effects. We analyzed the filters for chl $a$ and pheophytins and reported pigment concentrations as benthic chl $a\left(\mu \mathrm{g} / \mathrm{m}^{2}\right)$. We visually estimated total aquatic macrophyte and bryophyte \% cover at all sites during each sampling period.

\section{Data analyses}

We examined flow-regime stability by calculating the coefficient of variation (CV) for the ratio of mean annual stage or discharge to monthly mean stage or discharge at locations where we collected stage data (i.e., Castle Creek, Rising River, and Fall River) or where we were able to acquire discharge data from existing stream gauges (Hat Creek and McCloud River) (Sear et al. 1999). Neither stage nor discharge data were available for the South Fork Sacramento River, so we used discharge from a downstream US Geological Survey (USGS) gauge on the Sacramento River that records the same winter storm and runoff events. We used flow CVs to assign rivers to 1 of 3 flow-variability classes: highly stable $(\mathrm{CV} \leq 0.25)$, moderately fluctuating $(0.25<\mathrm{CV} \leq 0.50)$, or highly fluctuating $(0.50<\mathrm{CV} \leq 1.0)$. To assess temporal variability in water temperature between river types, we calculated daily mean, minimum, and maximum water temperature for each river during the study period. We used the daily averages to calculate the standard deviation (SD) for each month and each river to understand dispersion from the mean between river types. Last, we fit a sine/cosine function with 2 predictor variables to the daily average temperature data associated with each stream using the regression equation:

$$
\operatorname{Temp}_{d}=\mu+b_{1} \sin \left(\frac{2 \pi d}{365}\right)+b_{2} \cos \left(\frac{2 \pi d}{365}\right)
$$

where $d$ is the Julian date, $\mu$ is the annual mean temperature, and $b_{1}$ and $b_{2}$ are regression coefficients. We then ran a multiple linear regression, solved for the regression coefficients for each stream, and calculated annual temperature amplitude using the equation:

$$
A=\sqrt{\left(b_{1}^{2}+b_{2}^{2}\right)}
$$

where $A$ is the annual temperature amplitude and $b_{1}$ and $b_{2}$ are solved regression coefficients (Anderson 1971).

We calculated benthic invertebrate density (individuals [ind] $/ \mathrm{m}^{2}$ ) based on the fraction of each sample sorted and the area of stream bed sampled. To correct for nonnormality and heteroscedasticity, we $\ln (x)$ - or $\sqrt{ }(x)$ transformed data as appropriate before statistical tests. We used linear mixed-effects models to test for differences in taxonomic richness, Shannon-Wiener diversity, total invertebrate density, functional trait groups, POM, chl $a, \mathrm{NO}_{3}-\mathrm{N}$ and $\mathrm{SR}-\mathrm{PO}_{4}{ }^{3-}$ concentrations, and $\mathrm{pH}$ between river types. Each model included stream type as a fixed effect and individual streams as a random effect, thus allowing an estimate of the effect of stream type on invertebrate community composition (or environmental constituent) while controlling for differences between individual streams. Season and interaction terms were included in all models. We ran a parallel series of analyses that included an autoregressive (AR1) correlation structure for each dependent variable tested to assess the potential for temporal autocorrelation in our data sets. If the addition of the correlation structure significantly improved model fit, then we presented those results. To confirm normality, we used Shapiro-Wilk tests. When data violated assumptions of normality, we applied a $95^{\text {th }}$ percentile Winsorization to adjust the most extreme outliers (Tukey 1962). We then reran the linear mixed-effects model on the Winsorized data. We rarified taxonomic richness data prior to statistical analysis to account for the potential effects of invertebrate abundance on assemblage richness (Gotelli and Colwell 2001). We used a Welch $t$ test to examine potential differences in median bed particle size, temperature amplitude, and the CV for stage between river types.

We used nonmetric multidimensional scaling (NMDS) to visualize invertebrate assemblage differences between river types over all seasons. We $\sqrt{ }(x)$-transformed data prior to analysis and used Sørensen (Bray-Curtis) distance to measure dissimilarity between samples. We overlaid environmental factors as vectors within the NMDS ordination based on Pearson's correlation coefficients between each factor and ordination axis. For temperature, we used mean monthly temperature for the corresponding invertebrate sampling period. For stage, we used mean annual stage divided by mean monthly stage for each river as a measure of stage variability between river types at each seasonal period. We used indicator species analysis (Dufrêne and Legendre 1997) to identify those taxa that contributed to community distinction between river types. Indicator values are a function of relative presence and exclusivity of a particular taxon to river type over all sampling periods (McCune and Grace 2002).

We conducted statistical analyses in $\mathrm{R}$, using the lme4 (Bates et al. 2014) and nlme (Pinheiro et al. 2014) packages for linear mixed-effects models and the vegan (Oksanen et al. 2013), betapart (Baselga and Orme 2012), and ecodist (Goslee and Urban 2007) packages for NMDS. We used PC-ORD (McCune and Mefford 2006) to run indicator species analysis. 


\section{RESULTS}

\section{Abiotic variables}

$\mathrm{D}_{50}$ did not differ between spring-fed and runoff rivers ( $t$-test, $p=0.15)$, but spring-fed rivers exhibited smaller substrate classes, on average, than runoff rivers $\left(\mathrm{D}_{50}=28 \mathrm{~mm}\right.$ vs $\left.119 \mathrm{~mm}\right) . \mathrm{NO}_{3}-\mathrm{N}$ and SR-PO ${ }_{4}{ }^{3-}$ concentrations differed between spring-fed and runoff rivers $\left(F_{1,4}=96.7, p<0.001 ; F_{1,4}=189.14, p<0.001\right.$, respectively; Fig. 2A, B). Over all sampling periods, $\mathrm{NO}_{3}-\mathrm{N}$ and $\mathrm{SR}-\mathrm{PO}_{4}{ }^{3-}$ concentrations were, on average, $40 \times$ greater in spring-fed than runoff rivers.
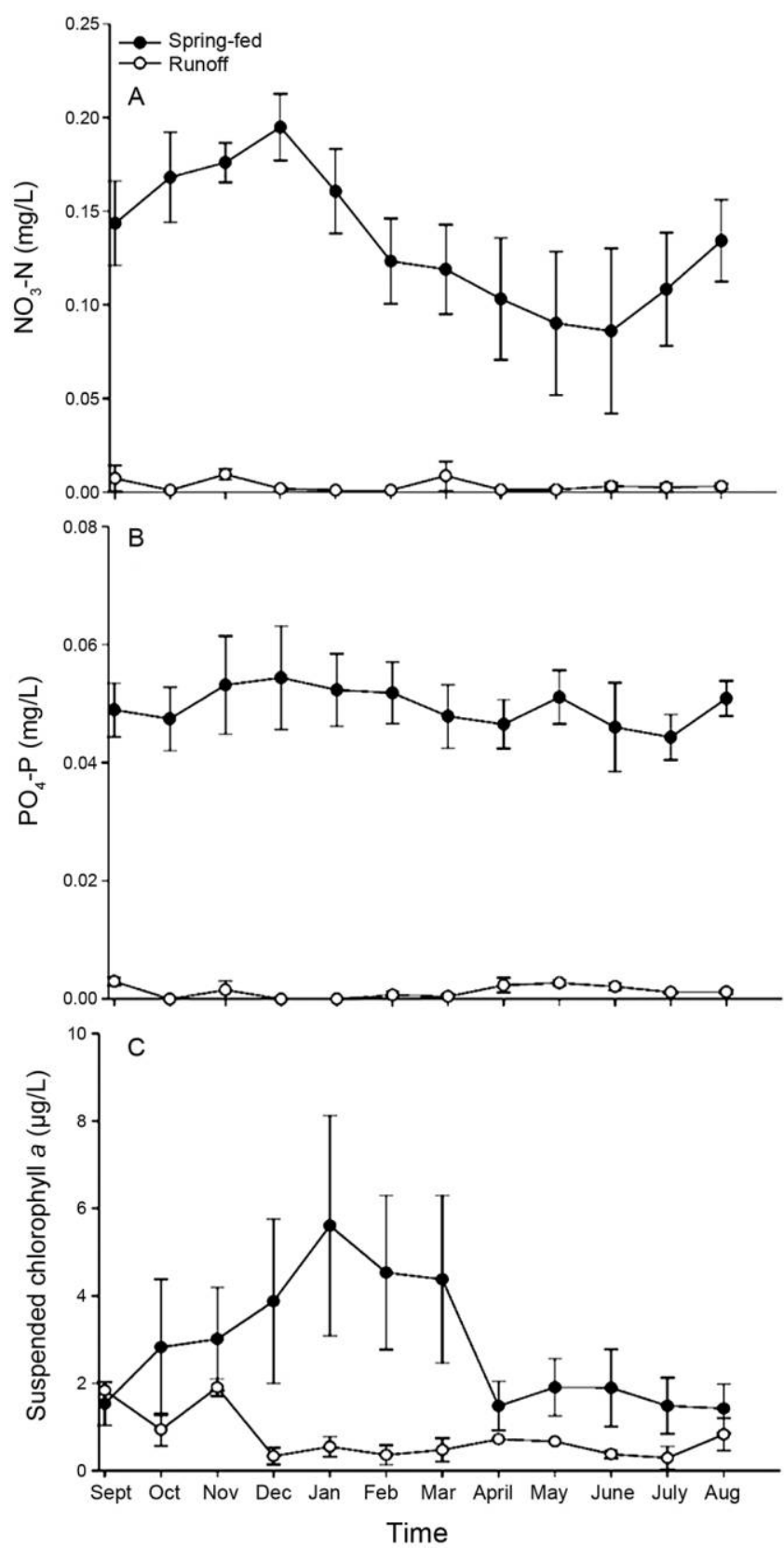

Figure 2. Mean $( \pm 1 \mathrm{SE})$ monthly streamwater $\mathrm{NO}_{3}-\mathrm{N}(\mathrm{A})$, soluble reactive $\mathrm{PO}_{4}-\mathrm{P}(\mathrm{B})$, and suspended chlorophyll $a(\mathrm{C})$ concentrations at runoff-dominated and spring-fed rivers.
Neither mean water temperature $\left(F_{1,4}=2.55, p=\right.$ $0.19)$ nor the difference in temperature amplitude $(t=$ $-2.41, \mathrm{df}=2.695, p=0.12$ ) differed between spring-fed and runoff rivers during the study period. However, both the SD and amplitude patterns associated with water temperature showed modest effect sizes (Fig. S1). Runoff rivers, on average, showed 1.12 SDs of the mean temperature, whereas spring-fed rivers exhibited $1 / 2$ this effect size at 0.66 SDs of the mean. Shifts in temperature amplitude were greater for runoff than spring-fed rivers. This pattern is best illustrated by the annual average thermograph for each river type, wherein spring-fed rivers clearly dampen the most extreme temperatures during winter and summer (Fig. 3). Last, the CV for stage/discharge differed markedly between river types ( $t$-test, $p<0.03$; Fig. S2). On average, spring-fed rivers were much more stable $(\mathrm{CV}=$ $0.08)$ than runoff rivers $(\mathrm{CV}=0.64)$.

\section{Biotic variables}

Basal resources. Neither FPOM nor CPOM differed between river types $\left(F_{1,4}=1.22, p=0.33 ; F_{1,4}=0.013, p=\right.$ 0.94; respectively). Overall mean CPOM values did not differ, but spring-fed rivers had a $26 \times$ increase in FPOM compared to runoff rivers during the July sampling period. Chlorophyll $a$ of benthic $\left(F_{1,4}=0.30, p=0.61\right)$ and suspended $\left(F_{1,4}=3.8, p=0.12\right)$ algae did not differ between river types. However, season affected chl $a$ of benthic algae in spring-fed and runoff rivers, with peak concentration during October and a strong decline through July $\left(F_{3,12}=\right.$ 5.98, $p<0.01)$. Season $\left(F_{11,36}=6.27, p<0.001\right)$ and season $\times$ river type $\left(F_{11,36}=4.64, p<0.001\right)$ affected chl $a$ of suspended algae (Fig. 2C). During the winter sampling period, suspended chl $a$ concentration increased $10 \times$ in springfed compared to runoff rivers. Bryophytes and macrophytes were observed only in spring-fed rivers and varied seasonally with peak channel coverage in summer and autumn sampling periods (Table 1).

Invertebrate abundance and diversity. We found strong differences in invertebrate density $\left(F_{1,4}=16.83, p<0.05\right)$ between river types (Fig. 4A). Over all sampling periods, spring-fed rivers supported nearly $7 \times$ greater invertebrate densities than runoff rivers. The differences were most pronounced in winter, when spring-fed rivers supported $16 \times$ higher densities than runoff rivers. Maximum densities occurred in autumn in runoff rivers $\left(2037 \mathrm{ind} / \mathrm{m}^{2}\right)$ and in summer in spring-fed rivers $\left(10,739 \mathrm{ind} / \mathrm{m}^{2}\right)$. Invertebrate density did not vary seasonally within river type.

We identified 155 distinct taxa over all sampling periods. After data were rarified, we found differences in taxonomic richness $\left(F_{1,4}=44.2, p<0.01\right.$; Fig. $\left.4 \mathrm{~B}\right)$ and ShannonWeiner diversity between river types $\left(F_{1,4}=15.31, p<0.05\right.$; Fig. 4C). Taxonomic richness was strongly seasonal, and both 


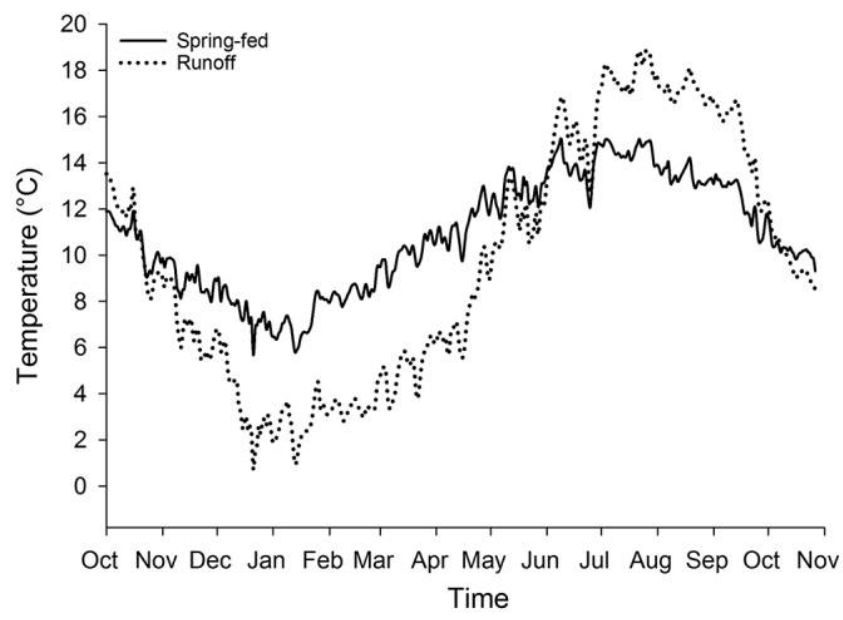

Figure 3. Mean daily water temperature at runoff-dominated and spring-fed rivers during the study period.

river types showed peak richness in July and declines in January $\left(F_{3,12}=32.98, p<0.001\right)$, but the magnitude of change was stronger in runoff rivers. Taxonomic richness was similar in spring-fed and runoff rivers in winter, but taxonomic richness in summer was nearly $2 \times$ higher in runoff than in spring-fed rivers.

Relative abundances of functional trait groups did not differ between river types, except for the predator functional guild $\left(F_{1,4}=22.45, p<0.01\right)$, which also showed a modestly strong seasonal effect $\left(F_{3,12}=4.82, p<0.05\right.$; Fig. S3). On average, relative abundances of predators were $5 \times$ higher in runoff than spring-fed rivers ( 21 vs $4 \%$, respectively) over all sampling periods. The relative abundance of predators was stable through time in spring-fed rivers, but it was far more variable in runoff rivers and exhibited a bimodal pattern with peaks in autumn and spring. No other seasonal effects were observed between river types for functional guilds, except grazers $\left(F_{3,12}=\right.$ 9.39, $p<0.01$ ), which had higher relative abundances in January for both river types.

Invertebrate community composition. Samples from spring-fed and runoff rivers were segregated along the first NMDS axis, but the arrangement of samples also suggested 3 distinct assemblage clusters (stress $=0.12$, cumulative $R^{2}=0.98$; Fig. 5). Within the spring-fed river cluster, Fall River samples exhibited lower NMDS axis 2 values than did samples from Rising River and Hat Creek. This distinct cluster of Fall River samples had higher water temperatures than samples from the other 2 spring-fed sites (Table 2, Fig. 5). Correlations were strong between several measured environmental variables and NMDS axes (Table 2). $\mathrm{NO}_{3}-\mathrm{N}, \mathrm{SR}-\mathrm{PO}_{4}{ }^{3-}$, suspended chl $a$, and FPOM were positively correlated with NMDS axis 1 $\left(r=0.77,0.89,0.71\right.$, and 0.49 , respectively), whereas $\mathrm{D}_{50}$ and stage variability were negatively correlated with axis 1 ( $r=-0.71$ and -0.47 , respectively). The only factor with a sizable correlation $(|r|>0.25)$ with NMDS axis 2 was mean monthly water temperature $(r=-0.27)$. Benthic chl $a(r=0.30)$ and CPOM $(r=0.37)$ were not strongly correlated with any compositional gradients in the NMDS ordination. Indicator species analysis revealed that 14 and 23 taxa were significant indicators for runoff and springfed rivers, respectively (Table 3). Mollusks (Gastropoda), mayflies (Ephemeroptera), and caddisflies (Trichoptera) were common indicators of spring-fed rivers, whereas flies (Diptera) were frequently indicators of runoff rivers. Predators accounted for 31 and 13\% of all significant indicators for runoff and spring-fed rivers, respectively. The caddisfly Amiocentrus aspilus and the gastropods Fluminicola and Juga were the only taxa always present in spring-fed rivers and exclusive to those systems (indicator value [IV] $=100$, $p<0.001)$. No taxon was present throughout all sampling periods and exclusive to runoff rivers, but several midge (Chironomidae) genera and the stonefly Sweltsa (Chloroperlidae) were strong indicators for runoff rivers (IV > 70).

\section{DISCUSSION}

Environmental characteristics and invertebrate community structure differed significantly between spring-fed and runoff rivers. As predicted, spring-fed rivers exhibited more stable flow regimes, muted seasonal temperature variability, and higher nutrient availability than runoff rivers. Spring-fed rivers also supported higher invertebrate

Table 1 . Total \% macrophyte and bryophyte coverage at each sampling reach between October 2012 and July 2013.

\begin{tabular}{llccrr}
\hline & & \multicolumn{3}{c}{ \% macrophyte/bryophyte cover } \\
\cline { 3 - 6 } \multicolumn{1}{c}{ River } & Type & October & January & May & July \\
\hline Fall River & Spring-fed & 60 & 25 & 50 & 60 \\
Hat Creek & Spring-fed & 75 & 10 & 50 & 70 \\
Rising River & Spring-fed & 95 & 5 & 75 & 90 \\
South Fork Sacramento River & Runoff & 0 & 0 & 0 & 0 \\
Castle Creek & Runoff & 0 & 0 & 0 & 0 \\
McCloud River & Runoff & 0 & 0 & 0 & 0 \\
\hline
\end{tabular}



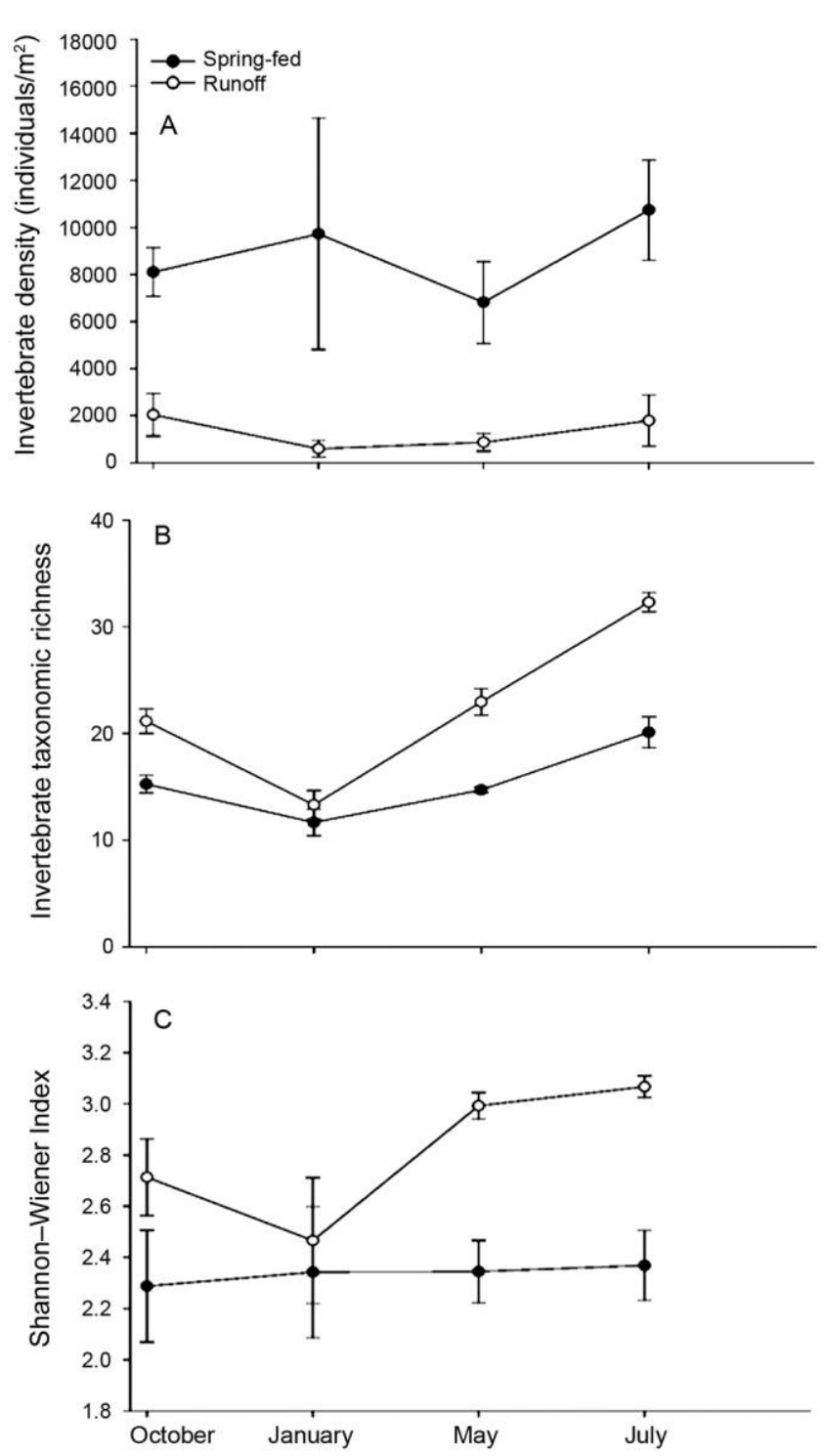

Figure 4. Mean $( \pm 1 \mathrm{SE})$ seasonal stream invertebrate density (A), rarified taxonomic richness (B), and Shannon-Weiner diversity $(\mathrm{C})$ at runoff-dominated and spring-fed rivers.

densities, but lower diversity than runoff rivers. Accordingly, spring-fed and runoff rivers supported distinct invertebrate communities.

\section{Invertebrate density}

Spring-fed rivers supported, on average, $7 \times$ greater invertebrate densities than runoff rivers over all sampling periods. These differences probably are attributable in large part to environmental variability between river types, with discharge, nutrient availability, and habitat playing particularly important roles. Discharge generally has an inverse relationship with invertebrate density (Suren and Jowett 2006, Benson et al. 2013). Streambed disturbance as a result of increasing discharge also has been implicated as a primary mechanism influencing invertebrate community change (Resh et al. 1988, Cobb et al. 1992, Townsend et al. 1997, Lake 2000, Tonkin and Death 2012). Hydraulic stress and sediment mobilization during peak discharge events probably contributed to the seasonal declines in invertebrate density in runoff rivers (Cobb et al. 1992).

Nutrient concentrations also influence invertebrate density in streams. Most stream ecosystems are naturally nutrient limited, and small increases in a limiting nutrient can enhance primary production with cascading effects on consumers (Hart and Robinson 1990, Slavik et al. 2004, Cross et al. 2006). We found that nutrient levels were significantly enhanced in spring-fed rivers and probably contributed to increased invertebrate density at these sites. Benstead et al. (2005) found that invertebrate abundance was 4 to $7 \times$ greater in an oligotrophic stream ecosystem after the addition of $\mathrm{N}$ and $\mathrm{P}$ and suggested that these changes were a result of enhanced food resources. Perrin and Richardson (1997) found that $\mathrm{N}$ and $\mathrm{P}$ additions to mesocosms increased mean invertebrate density by $70 \%$ over a period of $33 \mathrm{~d}$ and attributed their results to an increase in epilithic algal production.

Differences in nutrient concentrations between river types probably influenced invertebrate density via trophic pathways in our study, but differences in density also may result from habitat-mediated effects. Bryophytes and macrophytes can increase invertebrate density by increasing structural habitat complexity relative to complexity in typical stream bedforms, such as gravels (Brusven et al. 1990, Strayer and Malcom 2007, Shupryt and Stelzer 2009). Bryophytes

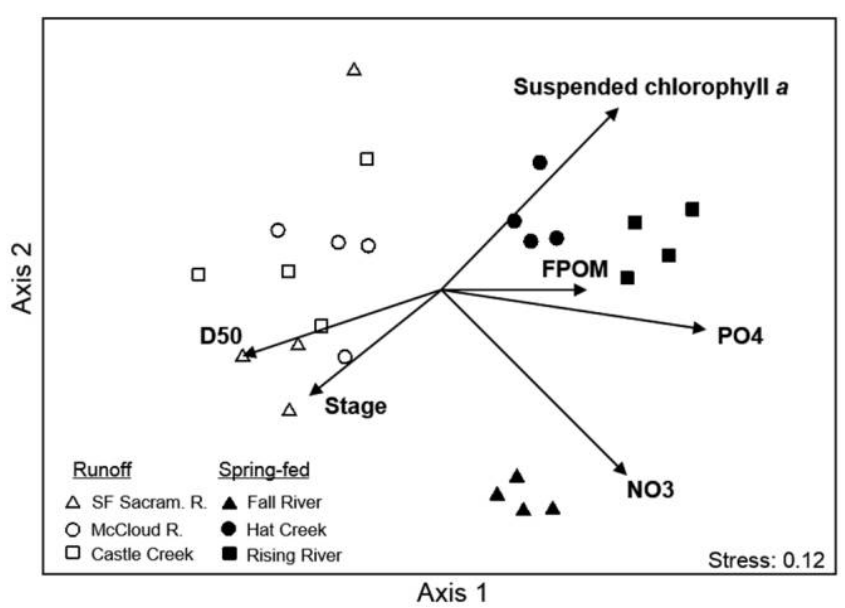

Figure 5. Nonmetric multidimensional scaling of invertebrate communities at runoff-dominated and spring-fed rivers over the entire study period with fitted environmental variables as vectors indicating the direction of environmental gradients (vector direction) and the strength of the gradient (length of vector). D50 = median particle size, $\mathrm{FPOM}=$ fine particulate organic matter, $\mathrm{PO} 4=$ soluble reactive $\mathrm{PO}_{4}{ }^{3-}, \mathrm{NO}_{3}-\mathrm{N}=\mathrm{NO}_{2}{ }^{-}+\mathrm{NO}_{3}{ }^{-}$, stage $=$ coefficient of variability for flow, SF Sacram. $=$ South Fork Sacramento, R. = river. 
Table 2. Linear correlations between measured environmental variables and invertebrate community nonmetric multidimensional scaling (NMDS) ordination axes for runoff and spring-fed rivers. $\mathrm{FPOM}=$ fine particulate organic matter, $\mathrm{CPOM}=$ coarse particulate organic matter.

\begin{tabular}{lccc}
\hline \multicolumn{1}{c}{ Environmental variable } & $r$ & NMDS axis & $p$ \\
\hline $\mathrm{NO}_{3}{ }^{-}$ & 0.77 & Axis 1 & 0.001 \\
$\mathrm{PO}_{4}{ }^{3-}$ & 0.89 & Axis 1 & 0.001 \\
Suspended chlorophyll $a$ & 0.71 & Axis 1 & 0.001 \\
Benthic chlorophyll $a$ & 0.30 & Axis 1 & 0.397 \\
FPOM & 0.49 & Axis 1 & 0.030 \\
CPOM & 0.37 & Axis 1 & 0.243 \\
Median bed particle size $\left(D_{50}\right)$ & -0.71 & Axis 1 & 0.002 \\
Mean monthly temperature & -0.27 & Axis 2 & 0.491 \\
Stage (coefficient of variation) & -0.47 & Axis 1 & 0.036 \\
\hline
\end{tabular}

and macrophytes were a dominant habitat feature in our spring-fed rivers, where they accounted for up to $95 \%$ of the entire sampling reach depending on season. Lusardi (2014) used a manipulative experiment to show that invertebrate densities were up to $9 \times$ greater on aquatic macrophytes than on gravel substrates in a spring-fed river in northern California. Thus, in addition to environmental stability and traditional bottom-up effects, differences in invertebrate density also may have been mediated through changes in functional habitat structure.

\section{Invertebrate diversity and community composition}

Runoff rivers supported greater invertebrate taxonomic diversity than did spring-fed rivers over all sampling periods. Few previous investigators have directly compared invertebrate diversity patterns between spring-fed and runoff systems. Barquín and Death (2004) found that runoff rivers supported higher invertebrate diversity than springfed streams in Spain. They attributed the lower diversity in spring-fed systems to several factors, including increased predation pressure by a dominant amphipod. In contrast, Barquín and Death (2006) found that invertebrate assemblages in New Zealand spring-fed streams were more diverse than those from runoff streams, and this result was corroborated by Tonkin and Death (2012). Barquín and Death (2006) suggested the pattern was caused by high environmental stability and resource levels in New Zealand spring-fed streams and by the fact that predator assemblages in these streams were more diverse than those in Spanish springs. Furthermore, they suggested that high invertebrate predator diversity in spring-fed systems meant that density-dependent mechanisms, such as predation, played an important role in regulating total invertebrate diversity.

We also found distinct invertebrate assemblages in spring-fed and runoff rivers, and increased flow variability was strongly associated with runoff-river assemblages (Table 2, Fig. 5). Barquín and Death (2006) did not explicitly measure flow variability, but they did find that invertebrate assemblages in New Zealand runoff streams were correlated with decreased habitat stability, which probably would be caused by increased flow variability. In Switzerland, von Fumetti and Nagel (2012) found that spring systems with higher discharge supported greater invertebrate diversity, and they suggested that high-flow events may create space for additional species colonization. High variability in stage and discharge during winter and spring floods in runoff rivers, as apparent in our study, is an important annual disturbance exerting strong selection pressure on stream biota and broader assemblage patterns (Resh et al. 1988, Lytle and Poff 2004). Population reductions associated with these high-flow events may reset the competitive landscape annually, keeping runoff rivers in a nonequilibrium state of low density and high species diversity (Connell 1978). Alternatively, Death and Barquín (2012) suggested that stream invertebrate diversitydisturbance relationships may be geographically dependent, relying instead on phylogenetics or life-history divergence.

We found that midge, stonefly, mayfly, mite, and riffle beetle taxa were indicative of runoff rivers, similar to runoff streams in Spain and New Zealand (Barquín and Death 2004, 2006). Many of these indicator taxa have adaptations to abiotic unpredictability. Several mayfly and midge genera indicative of our runoff rivers have short life cycles with rapid development to adult phases, enabling recolonization during variable flow events (Lytle and Poff 2004). Morphological adaptations, such as setose pads and dorsoventral flattening in mayfly genera (Heptageniidae) also enable individuals to increase frictional resistance or avoid turbulence all together during high discharge events in runoff rivers (Merritt et al. 2008, Ditsche-Kuru et al. 2010). In addition, some longer-lived runoff-river indicator spe- 
Table 3. Significant indicator species analysis values (IV $\geq 50)$ for spring-fed and runoff river types.

\begin{tabular}{|c|c|c|c|}
\hline River type & Taxon & IV & $p$ \\
\hline \multirow[t]{23}{*}{ Spring-fed } & Amiocentrus aspilus & 100 & 0.000 \\
\hline & Fluminicola & 100 & 0.000 \\
\hline & Juga & 100 & 0.000 \\
\hline & Isoperla & 95 & 0.000 \\
\hline & Oligochaeta & 92 & 0.000 \\
\hline & Baetis & 90 & 0.000 \\
\hline & Mucronothrus & 89 & 0.000 \\
\hline & Eukiefferiella devonica group & 83 & 0.001 \\
\hline & Sphaeriidae & 83 & 0.002 \\
\hline & Drunella & 81 & 0.010 \\
\hline & Isopoda & 78 & 0.000 \\
\hline & Zapada & 77 & 0.020 \\
\hline & Gammaridae & 75 & 0.003 \\
\hline & Heterlimnius & 74 & 0.001 \\
\hline & Micropsectra & 73 & 0.010 \\
\hline & Glossiphoniidae & 67 & 0.001 \\
\hline & Glossosoma & 64 & 0.020 \\
\hline & Pseudocloeon & 58 & 0.006 \\
\hline & Tricorythodes & 58 & 0.005 \\
\hline & Manayunkia & 50 & 0.010 \\
\hline & Nanocladius parvulus group & 50 & 0.020 \\
\hline & Physa & 50 & 0.010 \\
\hline & Vorticifex & 50 & 0.010 \\
\hline \multirow[t]{14}{*}{ Runoff } & Tanytarsus & 83 & 0.000 \\
\hline & Sweltsa & 82 & 0.001 \\
\hline & Polypedilum aviceps group & 76 & 0.001 \\
\hline & Torrenticola & 74 & 0.001 \\
\hline & Microtendipes rydalensis group & 73 & 0.001 \\
\hline & Bezzia & 64 & 0.008 \\
\hline & Sperchon & 64 & 0.010 \\
\hline & Ampumixis & 57 & 0.010 \\
\hline & Ameletus & 56 & 0.010 \\
\hline & Parametriocnemus & 56 & 0.020 \\
\hline & Rhithrogena & 55 & 0.020 \\
\hline & Hexatoma & 50 & 0.010 \\
\hline & Perlinodes & 50 & 0.010 \\
\hline & Zaitzevia & 50 & 0.010 \\
\hline
\end{tabular}

cies in our study, such as stoneflies of the genus Sweltsa, exhibit behavioral adaptations to deal with periodic drying or extreme low-flow events (Dieterich and Anderson 1995).

In contrast, the lack of flow disturbances and concomitant population reductions in spring-fed rivers suggest that species diversity and assemblage composition in these systems may be regulated by other mechanisms. Spring-fed assemblages in our study were strongly correlated with nutrients and food resources. Similar correlations between spring-fed invertebrate assemblages and elevated food resources have been reported from both Spain and New Zealand (Barquín and Death 2004, 2006). Nutrient availability and productivity have also been shown to positively affect invertebrate population growth rates and carrying capacity in other stream ecosystems (Slavik et al. 2004, Benstead et al. 2005).

Spring-fed rivers also exhibited relatively stable environmental conditions (e.g., flow regime and temperature). En- 
vironmental stability coupled with elevated nutrient concentrations and food resources in spring-fed rivers probably promoted the observed high densities of invertebrates. This situation suggests that as space becomes a limiting factor on invertebrate production, density-dependent interactions, such as competition, may play an increasingly important role in determining community composition. Resh et al. (1988) noted that spring-fed rivers may represent equilibrium conditions because of their inherent stability and suggested that biotic interactions, such as competition, may structure those invertebrate communities (also see Minshall et al. 1985). Ultimately, a relatively small number of taxa, including snails and caddisflies in our study, seem to be able to take full advantage of the benign flow conditions and elevated resources available in spring-fed rivers. These taxa have strong competitive traits that facilitate their dominance and, thus, may reduce overall taxonomic diversity in spring-fed rivers.

Two gastropod taxa, Juga and Fluminicola, were found exclusively in spring-fed rivers and were numerically dominant at those sites. For example, these 2 genera accounted for up to $1 / 4$ of all invertebrates sampled on the Fall River in winter. Hawkins and Furnish (1987) showed in a manipulative experiment that Juga depressed abundances of cooccurring invertebrate competitors through exploitative and interference competition. Others have shown that gastropods, through competitive interactions, can strongly affect resource levels and negatively affect density and diversity of competitor species (Hawkins and Furnish 1987, Hill 1992, Rosemond et al. 1993). In studies from Spain and New Zealand, gastropods (Hydrobiidae, Neritidae) were among the most abundant taxa in spring-fed streams (Barquín and Death 2004, 2006). Herbst et al. (2008) found that water chemistry associated with spring-fed rivers was conducive to gastropod growth and fitness, which could provide a foundation for competitive dominance. Barquín and Death (2006) also noted that amphipods (Gammaridae), another strong competitor (Nilsson and Otto 1977), were indicative of spring-fed streams in Spain, similar to our results from spring-fed rivers in northern California. Together, these observations suggest that interspecific competition may play a prominent role in structuring communities in spring-fed systems.

\section{Implications for climate change and conservation of coldwater ecosystems}

Regional climate change predictions indicate that runoff rivers in the western USA will experience earlier peak flow periods, prolonged periods of summer/autumn low flow, higher magnitude winter floods, and increases in water temperature (Stewart et al. 2004, 2005, Bryant 2009, Das et al. 2011). These changes may not bode well for lotic ectotherms. Climate change and associated shifts in abiotic conditions may greatly reduce invertebrate densi- ties, increase rates of extinction of rare species, change the timing of metamorphosis and emergence, affect growth rates, and alter sex ratios of aquatic species (Hogg and Williams 1996, Harper and Peckarsky 2006, Durance and Ormerod 2007). Spring-fed rivers may be particularly resilient to climate-induced effects associated with water temperature and discharge variability and may be uniquely positioned as critical habitat refuges for invertebrates and other coldwater ectotherms, such as salmonids.

Spring-fed systems in our study have less flow and temperature variability throughout the year and are colder during summer and warmer during winter than adjacent runoff streams (Figs 3, S2). Small spring-fed streams in Oregon (USA) are capable of buffering stream water temperature when compared with runoff streams (Tague et al. 2007). Spring-fed streams also are less prone to experience extreme low-flow conditions in response to climate change (Tague and Grant 2009). Moreover, spring-fed rivers in our study supported greater basal C resources (suspended chl $a$, FPOM) and invertebrate densities than runoff rivers. The potential role of food resources in mediating the negative effects of climate change on ectotherms is understudied (Wipfli and Baxter 2010). Increased metabolic activity associated with warming stream temperatures suggests that growth of coldwater biota (invertebrates and higher-order consumers, such as insectivorous fishes) will slow unless they can compensate with increased resource consumption (Railsback and Rose 1999). Increased consumption may not be possible in runoff rivers because of their oligotrophic nature, but stream invertebrates and fishes in spring-fed rivers may be able to compensate for small increases in water temperature if provided greater abundance of food resources (Nicieza and Metcalfe 1997). Many spring-fed rivers are already dammed or diverted, but their potential role as climate refuges for coldwater taxa strongly suggests they should be given high priority in conservation planning efforts.

\section{ACKNOWLEDGEMENTS}

We thank Carson Jeffres for help with preproject planning and site selection and Kyle Phillips, Derek Drolette, and Nick Corline for support in collecting and processing biological samples. We thank Neil Willits for input on statistical design and analysis. Special thanks are owed to Peter Stent, Jim Gilligan, Dick Boles, and the Rising River Fishing Club for access to the Fall River and Rising River and to Tony Orozco for providing Hat Creek discharge data. The manuscript was improved by the comments of Kate Boersma and 3 anonymous referees. This study was supported by funding from the US Bureau of Reclamation.

\section{LITERATURE CITED}

Allan, J. D., and M. M. Castillo 2007. Stream ecology: structure and function of running waters. $2^{\text {nd }}$ edition. Springer, Dordrecht, The Netherlands.

Anderson, T. W. 1971. The statistical analysis of time series. $1^{\text {st }}$ edition. Wiley-Interscience, New York. 
APHA (American Public Health Association). 1998. Standard methods for the examination of water and wastewater. $20^{\text {th }}$ edition. American Public Health Association, American Water Works Association, Water Environment Federation, Washington, DC.

Arismendi, I., M. Safeeq, S. L. Johnson, J. B. Dunham, and R. Haggerty. 2013. Increasing synchrony of high temperature and low flow in western North American streams: double trouble for coldwater biota? Hydrobiologia 712:61-70.

Barquín, J., and R. G. Death. 2004. Patterns of invertebrate diversity in streams and freshwater springs in Northern Spain. Archiv für Hydrobiologie 161:329-349.

Barquín, J., and R. G. Death. 2006. Spatial patterns of macroinvertebrate diversity in New Zealand springbrooks and rhithral streams. Journal of the North American Benthological Society 25:768-786.

Barquín, J., and R. G. Death. 2011. Downstream changes in springfed stream invertebrate communities: the effect of increased temperature range? Journal of Limnology 70:134-146.

Baselga, A., and C. D. L. Orme. 2012. betapart: an R package for the study of beta diversity. Methods in Ecology and Evolution 3:808-812.

Bates, D., M. Maechler, B. Bolker, and S. Walker. 2014. lme4: linear mixed-effects models using Eigen and S4. R package version 1.1-7. R Project for Statistical Computing, Vienna, Austria. (Available from: https://github.com/lme4/lme4/)

Benson, E. R., M. S. Wipfli, J. E. Clapcott, and N. F. Hughes. 2013. Relationships between ecosystem metabolism, benthic macroinvertebrate densities, and environmental variables in a sub-arctic Alaskan river. Hvdrobiologia 701:189-207.

Benstead, J. P., L. A. Deegan, B. J. Peterson, A. D. Huryn, W. B. Bowden, K. Suberkropp, K. M. Buzby, A. C. Green, and J. A. Vacca. 2005. Responses of a beaded Arctic stream to short-term N and P fertilisation. Freshwater Biology 50:277290.

Brusven, M. A., W. R. Meehan, and R. C. Biggam. 1990. The role of aquatic moss on community composition and drift of fish-food organisms. Hydrobiologia 196:39-50.

Bryant, M. D. 2009. Global climate change and potential effects on Pacific salmonids in freshwater ecosystems of southeast Alaska. Climatic Change 95:169-193.

Cantonati, M., L. Füreder, R. Gerecke, I. Jüttner, and E. J. Cox. 2012. Crenic habitats, hotspots for freshwater biodiversity conservation: toward an understanding of their ecology. Freshwater Science 31:463-480.

Cobb, D. G., T. D. Galloway, and J. F. Flannagan. 1992. Effects of discharge and substrate stability on density and species composition of stream insects. Canadian Journal of Fisheries and Aquatic Sciences 49:1788-1795.

Connell, J. H. 1978. Diversity in tropical rain forests and coral reefs: high diversity of trees and corals is maintained only in a non-equilibrium state. Science 199:1302-1310.

Cross, W. F., J. B. Wallace, A. D. Rosemond, and S. L. Eggert. 2006. Whole-system nutrient enrichment increases secondary production in a detritus-based ecosystem. Ecology 87:15561565.

Das, T., M. D. Dettinger, D. R. Cayan, and H. G. Hidalgo. 2011. Potential increase in floods in California's Sierra Nevada under future climate projections. Climatic Change 109:71-94.
Death, R. G., and J. Barquín. 2012. Geographic location alters the diversity-disturbance response. Freshwater Science 31:636646.

Death, R. G., and E. M. Zimmermann. 2005. Interaction between disturbance and primary productivity in determining stream invertebrate diversity. Oikos 111:392-402.

Dieterich, M., and N. H. Anderson. 1995. Life cycles and food habits of mayflies and stoneflies from temporary streams in western Oregon. Freshwater Biology 34:47-60.

Ditsche-Kuru, P., J. H. E. Koop, and S. N. Gorb. 2010. Underwater attachment in current: the role of setose attachment structures on the gills of the mayfly larvae Epeorus assimilis (Ephemeroptera, Heptageniidae). Journal of Experimental Biology 213:1950-1959.

Doane, T. A., and W. R. Horwáth. 2003. Spectrophotometric determination of nitrate with a single reagent. Analytical Letters 36:2713-2722.

Dufrêne, M., and P. Legendre. 1997. Species assemblages and indicator species: the need for a flexible asymmetrical approach. Ecological Monographs 67:345-366.

Durance, I., and S. J. Ormerod. 2007. Climate change effects on upland stream macroinvertebrates over a 25-year period. Global Change Biology 13:942-957.

Freeman, M. C., Z. H. Bowen, K. D. Bovee, and E. R. Irwin. 2001. Flow and habitat effects on juvenile fish abundance in natural and altered flow regimes. Ecological Applications 11:179190.

Goslee, S. C., and D. L. Urban. 2007. The ecodist package for dissimilarity-based analysis of ecological data. Lournal of Statistical Software 22:1-19.

Gotelli, N. J., and R. K. Colwell. 2001. Quantifying biodiversity: procedures and pitfalls in the measurement and comparison of species richness. Ecology Letters 4:379-391.

Greenwood, M. J., and D. J. Booker. 2014. The influence of antecedent floods on aquatic invertebrate diversity, abundance and community composition. Ecohydrology 8:188-203.

Harper, M. P., and B. L. Peckarsky. 2006. Emergence cues of a mayfly in a high-altitude stream ecosystem: potential response to climate change. Ecological Applications 16:612621.

Hart, D. D., and C. T. Robinson. 1990. Resource limitation in a stream community: phosphorus enrichment effects on periphyton and grazers. Ecology 71:1494-1502.

Hawkins, C. P., and J. K. Furnish. 1987. Are snails important competitors in stream ecosystems. Oikos 49:209-220.

Herbst, D. B., M. T. Bogan, and R. A. Lusardi. 2008. Low specific conductivity limits growth and survival of the New Zealand mudsnail from the upper Owens River, California. Western North American Naturalist 68:324-333.

Hill, W. R. 1992. Food limitation and interspecific competition in snail dominated streams. Canadian Journal of Fisheries and Aquatic Sciences 49:1257-1267.

Hogg, I. D., and D. D. Williams. 1996. Response of stream invertebrates to a global-warming thermal regime: an ecosystemlevel manipulation. Ecology 77:395-407.

Jacobsen, D., R. Schultz, and A. Encalada. 1997. Structure and diversity of stream invertebrate assemblages: the influence of temperature with altitude and latitude. Freshwater Biology $38: 247-261$. 
Lake, P. S. 2000. Disturbance, patchiness, and diversity in streams. Journal of the North American Benthological Society 19:573592.

Lusardi, R. A. 2014. Volcanic spring-fed rivers: ecosystem productivity and importance for Pacific salmonids. PhD Dissertation, University of California, Davis, California.

Lytle, D. A., and N. L. Poff. 2004. Adaptation to natural flow regimes. Trends in Ecology and Evolution 19:94-100.

McCune, B., and J. B. Grace. 2002. Analysis of ecological communities. MjM Software Design, Gleneden Beach, Oregon.

McCune, B., and M. J. Mefford. 2006. PC-ORD: multivariate analysis of ecological data. Version 5.0. MjM Software, Gleneden Beach, Oregon.

Merritt, R. W., K. W. Cummins, and M. B. Berg (editors). 2008. An introduction to the aquatic insects of North America. $4^{\text {th }}$ edition. Kendall/Hunt, Dubuque, Iowa.

Minshall, G. W., R. C. Petersen, and C. F. Nimz. 1985. Species richness in streams of different size from the same drainage basin. American Naturalist 125:16-38.

Nicieza, A. G., and N. B. Metcalfe. 1997. Growth compensation in juvenile Atlantic salmon: responses to depressed temperature and food availability. Ecology 78:2385-2400.

Nilsson, L. M., and C. Otto. 1977. Effects of population density and of presence of Gammarus pulex L. (Amphipoda) on growth in larvae of Potamophilax cingulatus Steph. (Trichoptera). Hydrobiologia 54:109-112.

NRC (National Research Council) 2004. Endangered and threatened fishes in the Klamath River Basin. National Academies Press, Washington, DC.

Oksanen, J., G. F. Blanchet, R. Kindt, P. Legendre, P. R. Minchin, R. B. O'Hara, G. L. Simpson, M. Solymos, M. H. Stevens, and H. Wagner. 2013. vegan: community ecology package. R package version 2.0-10. (R Project for Statistical Computing, Vienna, Austria. (Available from: https://github.com/vegandevs/vegan)

Peckarsky, B. L., S. C. Horn, and B. Statzner. 1990. Stonefly predation along a hydraulic gradient: a field test of the harsh benign hypothesis. Freshwater Biology 24:181-191.

Perrin, C. J., and J. S. Richardson. 1997. N and P limitation of benthos abundance in the Nechako River, British Columbia. Canadian Journal of Fisheries and Aquatic Sciences 54:25742583

Pinheiro, J., D. Bates, S. DebRoy, D. Sarkar, and R. C. D. Team. 2014. nlme: linear and nonlinear mixed effects models. R package version 3.1-118. R Project for Statistical Computing, Vienna, Austria. (Available from: https://cran.r-project.org/web /packages/nlme/index.html)

Railsback, S. F., and K. A. Rose. 1999. Bioenergetics modeling of stream trout growth: temperature and food consumption effects. Transactions of the American Fisheries Society 128:241256.

Resh, V. H., A. V. Brown, A. P. Covich, M. E. Gurtz, H. W. Li, G. W. Minshall, S. R. Reice, A. L. Sheldon, J. B. Wallace, and R. C. Wissmar. 1988. The role of disturbance in stream ecology. Journal of the North American Benthological Society 7:433-455.

Rose, T. P., M. L. Davisson, and R. E. Criss. 1996. Isotope jihydrology of voluminous cold springs in fractured rock from an active volcanic region, northeastern California. Journal of Hydrology 179:207-236.
Rosemond, A. D., P. J. Mulholland, and J. W. Elwood. 1993. Top-down and bottom-up control of stream periphyton: effects of nutrients and herbivores. Ecology 74:1264-1280.

Sear, D. A., P. D. Armitage, and F. H. Dawson. 1999. Groundwater dominated rivers. Hydrological Processes 13:255-276.

Shupryt, M. P., and R. S. Stelzer. 2009. Macrophyte beds contribute disproportionately to benthic invertebrate abundance and biomass in a sand plains stream. Hydrobiologia 632:329-339.

Slavik, K., B. J. Peterson, L. A. Deegan, W. B. Bowden, A. E. Hershey, and J. E. Hobbie. 2004. Long-term responses of the Kuparuk River ecosystem to phosphorus fertilization. Ecology 85:939-954.

Smith, D. G. 2001. Pennak's freshwater invertebrates of the United States. John Wiley and Sons, New York.

Stanley, E. H., D. L. Buschman, A. J. Boulton, N. B. Grimm, and S. G. Fisher. 1994. Invertebrate resistance and resilience to intermittency in a desert stream. American Midland Naturalist 131:288-300.

Stewart, I. T., D. R. Cayan, and M. D. Dettinger. 2004. Changes in snowmelt runoff timing in western North America under a 'business as usual' climate change scenario. Climatic Change 62:217-232.

Stewart, I. T., D. R. Cayan, and M. D. Dettinger. 2005. Changes toward earlier streamflow timing across western North America. Journal of Climate 18:1136-1155.

Strayer, D. L., and H. M. Malcom. 2007. Submersed vegetation as habitat for invertebrates in the Hudson River estuary. Estuaries and Coasts 30:253-264.

Suren, A. M., and I. G. Jowett. 2006. Effects of floods versus low flows on invertebrates in a New Zealand gravel-bed river. Freshwater Biology 51:2207-2227.

Tague, C., M. Farrell, G. Grant, S. Lewis, and S. Rey. 2007. Hydrogeologic controls on summer stream temperatures in the McKenzie River basin, Oregon. Hydrological Processes 21: 3288-3300.

Tague, C., and G. E. Grant. 2004. A geological framework for interpreting the low-flow regimes of Cascade streams, Willamette River Basin, Oregon. Water Resources Research 40(4). doi:10.1029/2003WR002629

Tague, C., and G. E. Grant. 2009. Groundwater dynamics mediate low-flow response to global warming in snow-dominated alpine regions. Water Resources Research 45:1-12.

Thorp, J. H., and A. P. Covich. 2001. Ecology and classification of North American freshwater invertebrates. Academic Press, San Diego, California.

Tonkin, J. D., and R. G. Death. 2012. Consistent effects of productivity and disturbance on diversity between landscapes. Ecosphere 3:1-19.

Townsend, C. R., M. R. Scarsbrook, and S. Dolédec. 1997. The intermediate disturbance hypothesis, refugia, and biodiversity in streams. Limnology and Oceanography 42:938-949.

Tukey, J. W. 1962. Future of data-analysis. Annals of Mathematical Statistics 33:1-67.

von Fumetti, S., and P. Nagel. 2012. Discharge variability and its effect on faunistic assemblages in springs. Freshwater Science 31:647-656.

Wenger, S. J., D. J. Isaak, C. H. Luce, H. M. Neville, K. D. Fausch, J. B. Dunham, D. C. Dauwalter, M. K. Young, M. M. Elsner, B. E. Rieman, A. F. Hamlet, and J. E. Williams. 2011. 
Flow regime, temperature, and biotic interactions drive differential declines of trout species under climate change. Proceedings of the National Academy of Sciences of the United States of America 108:14175-14180.

Whiting, P. J., and D. B. Moog. 2001. The geometric, sedimentologic and hydrologic attributes of spring-dominated channels in volcanic areas. Geomorphology 39:131-149.

Whiting, P. J., and J. Stamm. 1995. The hydrology and form of spring dominated channels. Geomorphology 12:233-240.
Wiggins, G. B. 1996. Larvae of the North American caddisfly genera (Trichoptera). $2^{\text {nd }}$ edition. University of Toronto Press, Toronto, Ontario.

Wipfli, M. S., and C. V. Baxter. 2010. Linking ecosystems, food webs, and fish production: subsidies in salmonid watersheds. Fisheries 35:373-387.

Wolman, M. G. 1954. A method of sampling coarse river-bed material. Transactions of the American Geophysical Union 35:951-956. 